\title{
On Quality Cultivation \& Career Development of College Students
}

\author{
Tingyan $\mathrm{Bi}^{1, \mathrm{a}}$, Binlu Feng ${ }^{2, \mathrm{~b},{ }^{*}}$ and Chenming $\mathrm{We}^{3, \mathrm{c}}$ \\ 1,2Weifang University, Institute of Higher Education, Weifang, China 261061 \\ 3Weifang University, School Of Teacher Education,Weifang, 261061 \\ abtylook@163.com, bb8877208@163.com, c8877208@163.com
}

Keywords: college students, quality, education, career.

\begin{abstract}
The condition of college students' quality and career has been concerned by all sectors of society. How to promote the college students' quality and make the guidance of their career development better, need implement the relevant policies conscientiously and improve the working mechanism through comprehensive reform. This need improve the education system of innovation and entrepreneurship, and make the evaluation mechanism more prefect by strengthening the construction of teachers' professional ideal and professional ethics and deepening the education and teaching reform.
\end{abstract}

\author{
大学生素质养成与职业生涯发展 \\ 毕廷延 $1, a$, 冯滨鲁 $2, b,{ }^{*}$, 魏晨明 $3, c$ \\ 1,2潍坊学院高教研究所, 潍坊, 中国 \\ 3淮坊学院教师教育学院, 潍坊, 中国 \\ abtylook@163.com, bb8877208@163.com, ‘8877208@163.com
}

关键词: 大学生; 素质; 教育; 职业生涯

中文摘要. 大学生的素质和职业生涯状况, 备受社会各界关注。推动大学生素质养成的提升, 做好大学生的职业生涯发展指导, 需要认真贯彻落实相关政策, 通过综合改革, 完善工作机 制, 加强教师职业理想和职业道德建设, 深化教育教学改革, 完善创新创业教育体系, 完善 评价机制。

\section{1. 引言}

扎根中国大地办大学, 关键是要体现中国特色。中国特色的灵魂是 “两个坚持、两个加 强”。所谓 “两个坚持”, 就是要坚持党的领导、坚持马克思主义指导; 所谓 “两个加强” , 就是要加强党的领导、加强马克思主义指导。高等学校人才培养的核心是提高大学生的素质。 素质是一个人品德、知识和能力的总称, 是人的内在性和外显性的统一, 是人的稳定性与发 展性的统一, 是人的个性与共性的统一, 是人的先天直接传递性和后天不可直接传递性的统 一。人素质的高低, 就是其品德、知识和能力的高低。品德包括世界观、价值观、人生观、 道德品质、人格鬼力等; 知识包括专业知识和非专业知识, 涉及知识结构、学习方法、思维 方法、学业水平等; 能力包括沟通表达、组织协调、分析判断、问题解决、身心状况、审美 能力、职业适应等。素质教育强调促进人的全面、个性发展, 促进知行合一、理论与实践相 结合。人的素质高低, 决定其职业生涯发展水平。素质高的人, 职业生涯发展的水平高; 素 质低的人, 很难有高的职业生涯发展水平。实施素质教育, 进行品德、知识和能力教育, 有 
利于提高人的职业生涯发展水平。很长一个阶段以来, 社会各界对于大学生的素质养成问题, 就业难、难就业等问题, 都有很多指责。出现这些问题, 该归各于政策、社会环境还是家庭、 学校教育，或是该归各于学生自身？众说纷纭，莫衷一是，值得商榷。

\section{2. 发展现状概述}

\section{1 成绩可喜}

麦可思研究院发布的《2016年中国大学生就业报告》显示，中国目前虽然面临经济下行 压力大的形势, 但大学生创业、深造确保了就业率继续保持稳定, 自主创业比例持续上升, 自主创业存活率明显提升, 自主创业的毕业生收入优势明显。中国为实施创新驱动战略, 推 动以创业带动就业, 构建了学生创新能力提升体系, 有效破解高校毕业生就业难的问题。2016 年，教育部举办的第二届中国 “互联网+” 大学生创新创业大赛，吸引了31个省份2110所高校 学生提交项目作品, 参与高校占全国普通高校总数的 $81 \%$ 。这场主题为 “拥抱 “互联网+' 时 代共筑创新创业梦想” 的大赛, 目的是通过深化高等教育综合改革, 激发大学生的创造力, 培养造就 “大众创业、万众创新” 的生力军; 推动赛事成果转化和产学研用紧密结合, 促进 “互联网+” 新业态形成, 服务经济提质增效升级; 以创新引领创业、创业带动就业, 推动高 校毕业生更高质量创业就业。[1]中国虽然还处在经济体制深刻变革、社会结构深刻变动、利 益格局深刻调整、思想观念深刻变化的改革攻坚期、矛盾凸显期、发展关键期, 存在不少需 要规范矫正的问题, 但当代大学生的价值观总体上是积极向上的。 ${ }^{[2]}$ 调查结果虽然反映出来 大学生思想政治状况中存在一些值得关注的问题和当前大学生思想政治教育面临的新形势、 新任务，但中国大学生思想主流积极健康、向上向好。[3]

\section{2 问题突出}

中国大学生的素质养成, 依然面临知识结构不合理、教育教学不科学等问题。过分追求 “形式”上的教育公平而失去了教育质量。“分数面前人人平等” 的惯性思维和现实考量, 使得教育陷入 “应试教育” 的泥潭不能自拔, 过分看重 “分数” 而忽视了素质养成教育的情 况不容乐观。 ${ }^{[4]}$ 大学生的言谈行为、道德素质、学习状况、职业适应、身体状况、心理状态, 经常差强人意, 与时代不符, 与经济社会发展不符, 与社会、学校、家庭乃至学生个人的期 望不符。越来越呈现出功利化倾向, 日益转化为求职竞聘速成班、创业速成班、考研速成班。 [5]对于这些问题, 应该认真研究, 采取积极有效措施, 切实加以解决。

\section{3. 问题分析}

不少高校强调课堂理论教学而忽视实践教学，重视课堂育人而忽视实践育人，重视教书 育人而忽视协同育人。理论知识与生动活泼的社会实践相隔绝, 学生的创新精神、实践能力 被压抑，难以得到实际的提高，导致知行分离。中国高等教育大而不强、教育质量不高的问 题依然突出, 与世界发达国家相比, 差距依然明显。教育部长陈宝生认为: “教学决定生存, 离开教学, 校长不是校长、教授不是教授、大学不是大学, 学校就没有了。”随着中国高等 教育综合改革的深入实施, 面临的问题越来越突出, 重点、措施、办学理念都应做出相应的 调整。高校要增强办学理念, 重视教学实践。马克思关于人的全面发展的学说, 是中国教育 的理论基础。在职业生涯环境中, 大学生追求更高学位和获得工作经验是积累人力资本的两 条路径，高校要通过完整、系统的知识体系讲授，提升大学生的认知能力。[6]

高校要勉励大学生志存高远脚踏实地, 转变择业观念, 坚持从实际出发, 勇于到基层一 线和艰苦地方去, 把人生的路一步步走稳走实, 善于在平凡岗位上创造不平凡的业绩。 ${ }^{[7]}$ 随 着大学生 “就业难、难就业” 问题的突显, 社会各界越来越关注大学生的职业生涯教育问题。 人生的扣子从一开始就要扣好。如果第一粒扣子扣错了, 剩余的扣子都会扣错。人生的扣子 从一开始就要扣好。他要鼓励广大青年勤学、修德、明辨、笃实, 在时代大潮中建功立业, 
成就自己宝贵的人生。[8]大学生要高度重视当下的时光, 谋划人生、创造历史。中国职业生 涯规划教育从上世纪九十年代开始, 强调职业在人生发展中的重要地位, 重在关注学生的全 面发展和终身发展, 促使学生理性地规划未来, 努力在学习过程中自觉地提高就业能力和生 涯管理能力。[9]引起工作动机的因素主要有激励和保健两个因素。只有激励因素才能够给人 们带来满意感, 从而提高工作积极性; 而保健因素只能消除人们的不满, 但不会带来满意感。 影响大学生基层就业意愿的因素有激励和排斥两个因素。激励因素是推动参与基层就业项目 的因素，排斥因素是阻碍其参与的因素。[10]实施中国制造2025、互联网，，一带一路战略， 推动传统产业转型升级, 存在大量稳定和提升现有岗位、创造新岗位的机会。[11]只要完善大 学生就业创业政策体系, 健全生涯发展指导服务体系, 让学生在校和离校后都能接受职业指 导、职业规划和创业服务，就能提高毕业生的就业质量。

\section{4. 对策建议}

\section{1 加强教师职业理想和职业道德建设}

高校教师要做 “有理想信念、有道德情操、有扎实知识、有仁爱之心” 的“四有”好老 师。为增强广大教师教书育人的责任感和使命感, 引导广大教师自觉践行社会主义核心价值 体系, 加强自身修养, 弘扬高尚师德。适应教育发展新形势, 建立健全高校师德建设长效机 制的主要举措, 创新师德教育, 引导教师树立崇高理想; 加强师德宣传, 培育重德养德良好 风尚; 健全师德考核, 促进教师提高自身修养; 强化师德监督, 有效防止师德失范行为; 注 重师德激励，引导教师提升精神境界；严格师德惩处，发挥制度规范约束作用。

\section{2 深化教育综合改革}

台激励教师尽兴教书、潜心育人的政策措施，颁布实施本科专业类分类标准，出台课堂 教学管理办法, 努力实现以信息化为手段扩大优质教育资源覆盖面, 以教育信息化带动教育 现代化。地方高校转型成功的标志是办好具有特色、满足地方经济发展需求的本科教育, 地 方高校教育受众多元化, 学生来源渠道多元, 人才培养要增强针对性, 因材施教, 分类培养, 要彰显应用型分类培养方案。[12]加强高校实践育人。搭建课堂内外深度融合、组建师生协同 合作、构建多方资源协调统一的培育共同体。政府、高校、家庭和社会要通力协作，专业课 程、校园文化、教师和学生等教育教学环节要协调一致。加强高校体育教育。通过建立健全 学校体育的监测评价机制, 督促高校创新工作体制机制, 实施好体育课程和课外体育活动, 加强学校体育教师队伍建设, 加快学校体育设施建设, 健全学校体育风险管理体系。加强高 校美育教育。加强大学生的职业生涯教育。大学生的职业意识、职业规划、就业能力、求职 过程、职业适应、创业教育等与大学生职业发展之间有内在必然的联系。[13]

\section{3 完善创新创业教育体系}

深化教育综合改革，推进素质教育，创新教育方法。要采取积极有效措施，激励大学生 投身创新创业, 提高实践能力。要边学习边创业, 把学到的知识用于实践当中。既要向书本 学习, 也要向实践学习。为促进学生全面发展, 推动毕业生创业就业, 建立健全课堂教学、 自主学习、结合实践、指导帮扶、文化引领融为一体的高校创新创业教育体系, 提高学生的 创新精神、创业意识和创新创业能力; 健全创新创业教育课程体系, 改革教学方法和考核方 式, 创新人才培养机制, 完善人才培养质量标准, 强化创新创业实践, 改进学生创业指导服 务, 加强教师创新创业教育教学能力建设, 改革教学和学籍管理制度, 完善创新创业资金支 持和政策保障体系。

\section{4 完善评价机制}

为深化高等教育领域综合改革，破除束缚高校教师发展的体制机制障碍，激发高校教师 教书育人、科学研究、创新创业活力, 切实加强高校教师队伍建设。考核评价改革坚持正确 
方向, 以师德为先、教学为要、科研为基、发展为本, 注重德才兼备, 凭能力、实绩和贡献 评价教师, 克服了以往的唯学历、唯职称、唯论文等倾向。考核评价以问题为导向, 有利于 纠正教师从事教育教学工作重视不够的问题。

\section{致谢}

本文系潍坊学院教改项目《应用型高校的一流本科教育研究》（2016GZ001）、山东省 社科规划项目《地方高校与半岛经济区建设互动研究》（09CJGJ48）的阶段性成果之一。

\section{References}

[1] Weiwei Li. 54 thousand students participate in the second China "Internet +" college students innovation and entrepreneurship contest. China Education Newspaper, 2016-09-23.

[2] Ming Li. The values of contemporary college students are generally positive. People's Daily, 2015-05-14(07).

[3] Ministry of Education website[DB/OL]. http://www.moe.gov.cn/, 2016-05-31.

[4] People'sNetwork[DB/OL].http://cpc.people.com.cn/pinglun/n/2015/1208/c241220-27900503.ht $\mathrm{ml}$.

[5] Qiang Han. Innovating College Students' Career Planning Education. China Education Newspaper, 2016-08-04. .

[6] Aiai Fan. Future - oriented College Students' Ability Development. Guangming Daily, 2016-02-25.

[7] Shoulun Wang. Return to the Essence of Career Education. New View on Career Development of College, Beijing: China Science and Technology Press, 2010.

[8] [13] Ruilin Wang. Order one. New View on Career Development of College, Beijing: China Science and Technology Press, 2010.

[9] Ping Yang. Hat affects college students to grass-roots employment, Guangming Daily, 2015-08-11.

[10]Bingzhi Han. Economic Transition to Provide New Opportunities for College Students' Employment, Economic Daily, 2016-06-06.

[11]Jianjun Hu. Actively Constructing the Community for Cultivating Students' Practical Abilities, Guangming Daily, 2015-03-30.

[12]Binlu Feng. Exploring the Transformation and Development of Local Colleges and Universities, Promote the construction of high - level applied universities, China Higher Education Research, vol.12, p.33, 2016. 